\title{
INFLUENCE OF SOIL COMPACTION ON OIL PALM YIELD
}

\begin{abstract}
ZURAIDAH, $\mathbf{Y}^{*}$
ABSTRACT
The threat of soil compaction is greater today because of the marked increase in the size and weight of machinery used in oil palm plantations. Concern has grown on their direct effects on soil physical properties and indirect effects on crop yield. Therefore, the objective of this study was to determine the influence of soil compaction on yield of oil palm planted on a clay-textured Bernam soil series (Typic Endoaquepts). Compaction treatments were imposed for six consecutive years with combination treatments of trailer weights and transportation frequencies. Although soil compaction was expected to reduce the oil palm yield, the results showed that an increase in soil bulk density (BD) and reduction in total porosity (TP) were beneficial to the oil palm. The fresh fruit bunch (FFB) yield, bunch number, and bunch weight were significantly increased by about $8 \%-11 \%, 7 \%-9 \%$, and $2 \%-3 \%$ respectively, in the compacted plots as compared to control. The three rounds (3R) per month transportation frequency resulted in higher FFB yield and bunch numbers for all compaction treatments. Thus, compaction may not be a problem to oil palm planted on Bernam soil series, but further study needs to be carried out on other soil series.
\end{abstract}

Keywords: soil compaction, oil palm, FFB yield, trailer weight, bulk density, total porosity.

Date received: 3 January 2018; Sent for revision: 4 January 2018; Received in final form: 13 August 2018; Accepted: 20 December 2018.

\section{INTRODUCTION}

Palm oil industry has been and would always be an important industry in the Malaysian economy as its contribution towards national growth could never be doubted. Oil palm planted area reached 5.74 million hectares in 2016 (Kushairi et al., 2018); hence labour demand is expected to increase. However, the major problem faced by the plantations is the unavailability of adequate labour for handling the laborious chores such as harvesting and collection of harvested bunches along with the loose fruits on the ground. This will be a continuing issue in the oil palm plantation sector as they have to rely entirely on foreign workers. Therefore, to address the labour shortage, the current productivity of

\footnotetext{
Malaysian Palm Oil Board,

6 Persiaran Institusi, Bandar Baru Bangi,

43000 Kajang, Selangor, Malaysia.

E-mail: zuraida@mpob.gov.my
}

workers has to be increased through mechanisation in field operations which involve the introduction of machines. Over the years, the industry has adopted several mechanisation operations in various field activities as to reduce dependency on foreign labour and to improve their efficiency.

However, one of the main concerns regarding mechanisation in oil palm plantations is soil compaction due to repeated traffic of various machines, especially on the harvesting paths. Heavy machinery used in oil palm plantation for carrying out most cultural practices could cause soil degradation, i.e. soil compaction which could be a significant problem in soils planted with oil palm. Compaction induced by mechanisation would have adverse effects on several key soil physical properties such as bulk density (BD), mechanical impedance, total porosity (TP) and hydraulic conductivity (Hamza and Anderson, 2005). The mechanised field operations also contributed to deterioration in soil physical properties (Zuraidah et al., 2015a) as 
compaction changes structural characteristics and functions of soil, which could have an effect on the yield. The initial indicator of soil compaction is an increment in the soil BD. Eventually, root growth and function would be restricted when BD exceeds a certain limit and consequently affecting the plant productivity.

Crop yields can be reduced by soil compaction due to increased resistance that could hinder root growth. Hence, limiting the amount of soil explored and retards the development of an extensive root system. This consequently influences the root growth and performance in relation to nutrient uptake and water use efficiencies (Chan et al., 2005; Hamza and Anderson, 2005). Compacted soil leads to greater resistance for roots to penetrate compacted soil layers due to increased BD and reduced TP. Consequently, the soil has poor aeration, with inadequate water and nutrient accessibility to plants. These are the major restrictions to plant growth and resulting in yield reduction (Lipiec et al., 2003; Glab, 2007; Usaborisut and Niyamapa, 2010; Baiyeri, 2015).

The current improved oil palm planting materials mature within 30 months after field planting with good management practices and produces fruit bunches throughout the year. They continue bearing fruits up to 25 years or more depending on the replanting schedule. Oil palm responses resulting from compaction treatments are related to the alterations of soil's physical properties which has an influence in water and nutrient availability. Hence, soil health should not be neglected when performing all management activities in order to obtain optimum (FFB) yield production. Raper and Kirby (2006), as well as Mari and Changying (2008), found that the effect of compaction on plant yield could be either beneficial or detrimental, depending on the compaction intensity. Hence, soil compaction in oil palm plantations could be minimised if the machines used are of appropriate size and weight, compatible to the soil type and textural classification. This would lessen the environmental deterioration with possible adverse effects on yield. The effect of soil compaction on oil palm yield should be the primary concern. Therefore, this study was initiated to get a better understanding of the mechanisation influence on oil palm yield.

\section{MATERIALS AND METHODS}

This study was conducted in a flat terrain of marine clay identified to be Bernam soil series (Typic Endoaquepts) in an oil palm estate. It is located at $4^{\circ} 00^{\prime} 20.96268^{\prime \prime} \mathrm{N}$ and $100^{\circ} 50^{\prime} 18.66199^{\prime \prime} \mathrm{E}$ of Malaysia. All the scheduled field activities at the study site including fertiliser applications, weeding, FFB harvesting, and evacuation were conducted manually. The planting density was 148 palms ha-1. The compaction treatments were a combination of three different trailer weights and three transportation frequencies. A tractor without a trailer (0T), tractor with $2 \mathrm{t}$ trailer weight (2T) and tractor with $4 \mathrm{t}$ trailer weight $(4 \mathrm{~T})$. There was no motorised vehicle traffic in the control plots where all field operations were carried out manually. The three transportation frequencies were 1 round $(1 R), 2$ rounds (2R) and 3 rounds (3R) monthly. The treatments were applied for six consecutive years and each treatment was implemented in five replications.

A systematic design was used in this study, where the experimental design was laid out without any randomisation due to physical constraints. Soil samplings were done twice a year. Undisturbed soil samples were taken at sampling depths of $0-10$, 10-20 and 20-30 cm for determination of soil physical properties. Soil particle density was determined using pycnometer while BD was determined using the core method (Blake and Hartge, 1986). Soil TP was then derived mathematically from the BD and particle density. The soil moisture characteristics determination was performed using pressure plate extractor (Townend et al., 2001). Field measurements of soil infiltration rate and hydraulic conductivity were done using Mini Disk Infiltrometer. Details of the methods and experimental layout of this study are as described in the previous article by Zuraidah et al. (2015a). FFB yield records were taken at each harvesting round of 10 to 12 days. The harvested FFB number and weight were recorded from the 16 recording palms per plot.

All data collected were analysed to determine significant trends between and within treatments on soil physical properties as well as on the palm FFB yield, bunch number and bunch weight. Tukey's test (post-hoc HSD analysis, $\alpha=0.05$ ) in conjunction with an ANOVA was used for multiple comparisons, where appropriate. All testing was accomplished using the IBM SPSS Statistics software program.

\section{RESULTS AND DISCUSSIONS}

The soil BD increased significantly resulting in reduced $\mathrm{TP}$ in plots compacted by $4 \mathrm{~T}$ trailer weight (Table 1). The BD of $4 \mathrm{~T}$ plots was significantly increased $(\mathrm{p} \leq 0.05)$ by about $9.6 \%$ from $0.8670 \mathrm{~g} \mathrm{~cm}^{-3}$ to $0.9504 \mathrm{~g} \mathrm{~cm}^{-3}$. In contrast, due to the increase in $\mathrm{BD}$, the soil TP had significantly reduced $(\mathrm{p} \leq 0.05)$ by about $4.7 \%$ from $67.269 \%$ to $64.138 \%$. The most immediate effect of soil compaction is an increase in the soil BD and reduction in TP. After six years of compaction treatments, the higher BD and lower TP values in this compacted plots suggest the risk of compaction due to heavy machinery. Similar results 
TABLE 1. SOIL BULK DENSITY AND TOTAL POROSITY AFFECTED BY THE TREATMENTS

\begin{tabular}{lcc}
\hline Trailer weight & $\begin{array}{c}\text { Soil bulk density } \\
\left(\mathbf{g ~ c m}^{-3}\right)\end{array}$ & $\begin{array}{c}\text { Soil total porosity } \\
\mathbf{( \% )}\end{array}$ \\
\hline Control & $0.87 \pm 0.02 \mathrm{a}$ & $67.3 \pm 0.7 \mathrm{a}$ \\
$0 \mathrm{~T}$ & $0.88 \pm 0.02 \mathrm{a}$ & $66.8 \pm 0.7 \mathrm{a}$ \\
$2 \mathrm{~T}$ & $0.86 \pm 0.02 \mathrm{a}$ & $67.5 \pm 0.7 \mathrm{a}$ \\
$4 \mathrm{~T}$ & $0.95 \pm 0.02 \mathrm{~b}$ & $64.1 \pm 0.7 \mathrm{~b}$ \\
\hline
\end{tabular}

Note: Means with the same letter in a column for each trailer weight are not significantly different at $5 \%$.

were reported by Cassel et al. (1995), Al-Ghazal (2002) and Ares et al. (2005).

The soil BD and TP were also affected by the transportation frequencies especially when applied at three rounds (3R) per month. Application of all the three trailer weights at $3 R$ per month contributed to a significant increase of soil BD by about $8 \%-12 \%$ $\left(0.884-0.990 \mathrm{~g} \mathrm{~cm}^{-3}\right)$ as compared to $1 \mathrm{R}(0.852-0.917$ $\left.\mathrm{g} \mathrm{cm}^{-3}\right)$. In contrast, the soil TP was significantly reduced by about $4 \%-6 \%(62.66 \%-66.65 \%)$ at $3 \mathrm{R}$ as compared to $1 \mathrm{R}(65.37 \%-67.84 \%)$ as shown in Figure 1. The combined effect of heavier weight and higher transportation frequency resulted in greater damage to the soil. All the three trailer weights had significant effects on the soil BD and TP for $3 \mathrm{R}$ transportation frequency. Both $0 \mathrm{~T}$ and $2 \mathrm{~T}$ treatments showed similar effects on soil $\mathrm{BD}$ and TP for $1 R$ and $2 R$ but significantly higher at $3 R$. However, for the $4 \mathrm{~T}$, the soil BD was significantly increased and TP decreased with increasing number of transportation frequency. A similar pattern was observed by Zhang et al. (2006), Pagliai et al. (2003) and Kamaruzaman (1991). This indicates that the transportation frequency for heavier machines plays an important role in the establishment of compacted soil.

Resulting from BD increment accompanied by TP reduction, soil pores are consequently being altered. Rearrangement of soil particles results in alteration of both pore size and their distribution. Macropores are important for drainage and aeration through the soil profile. Soil macropores collapse during compression of machinery used, thereby reducing the space available for water and air in the soil. Macropores reduction results in lower infiltration rate as well as a decrease in hydraulic conductivity (Zuraidah et al., 2015a). These changes can directly influence soil productivity. Regardless of the importance of soil fertility, good management of soil physical characteristics could contribute to improved yield through better fertiliser utilisation.

Previous studies done by Hanna and Mahdi (2002), Abu-Hamdeh (2003) and DeJong-Huges et al. (2001) had showed that soil compaction caused crop yield reduction. Thus, it was expected that the oil palm yield would be lower in the compacted plots. On the contrary, Figure $2 a$ shows that the FFB yield was significantly increased $(\mathrm{p} \leq 0.05)$ by about $8 \%$ $11 \%$ in the compacted plots as compared to control. It was increased from $36.3 \mathrm{t} \mathrm{ha}^{-1} \mathrm{yr}^{-1}$ in control plots to $39.3,39.6$ and $40.3 \mathrm{tha}^{-1} \mathrm{yr}^{-1}$ in the $0 \mathrm{~T}, 2 \mathrm{~T}$, and $4 \mathrm{~T}$ plots respectively. Hence, the increment in soil $\mathrm{BD}$ and reductions in TP were found to be beneficial to the oil palm in this study site which resulted in producing a higher yield. Figure $2 b$ shows that the mean FFB yield was significantly increased with increasing transportation frequency, with $3 R$ transportation frequency producing the highest FFB yield.

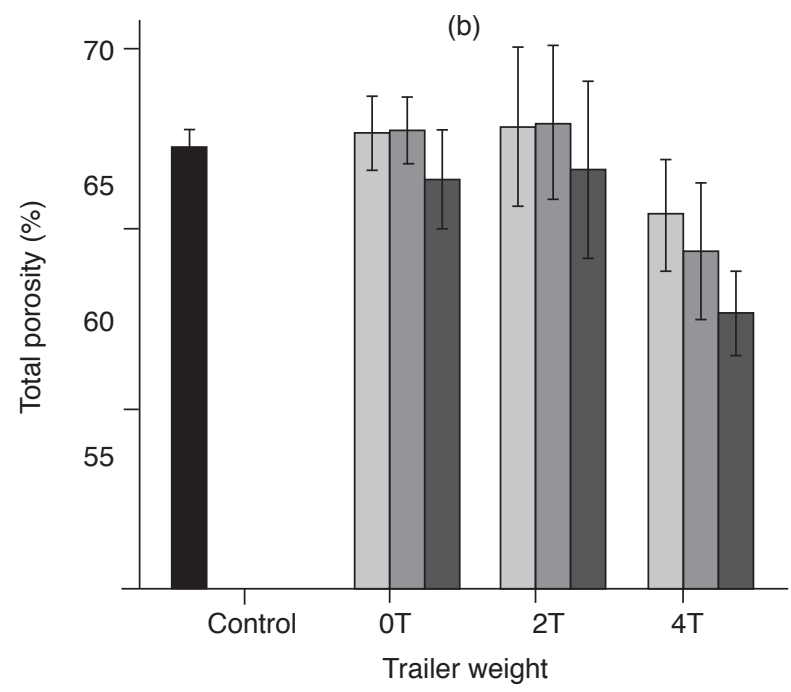

Transportation frequency

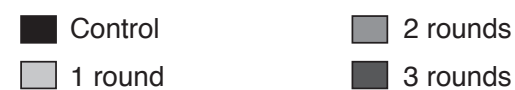

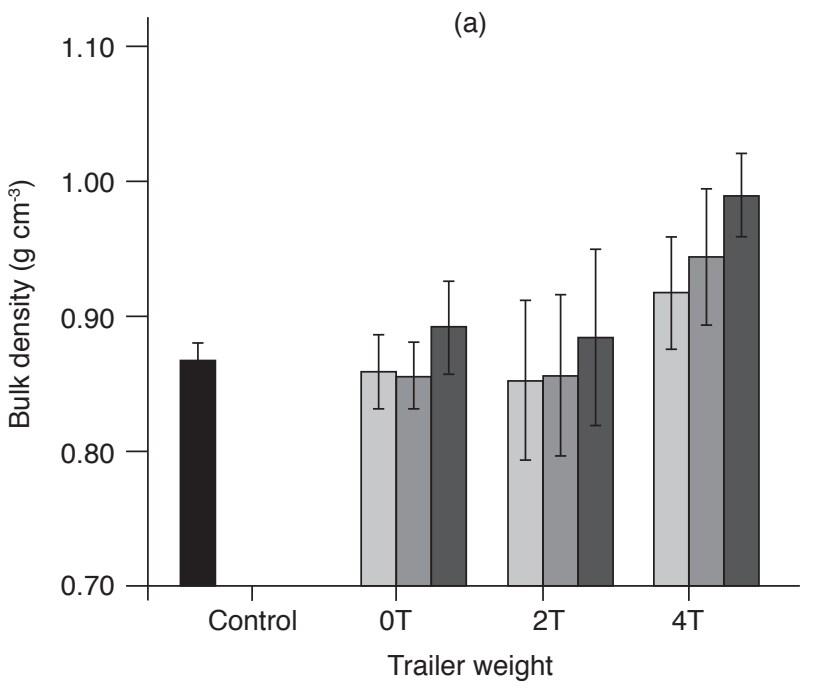

Transportation frequency

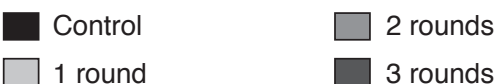

Figure 1. Soil bulk density (a) and total porosity (b) affected by different trailer weights with three transportation frequencies. 

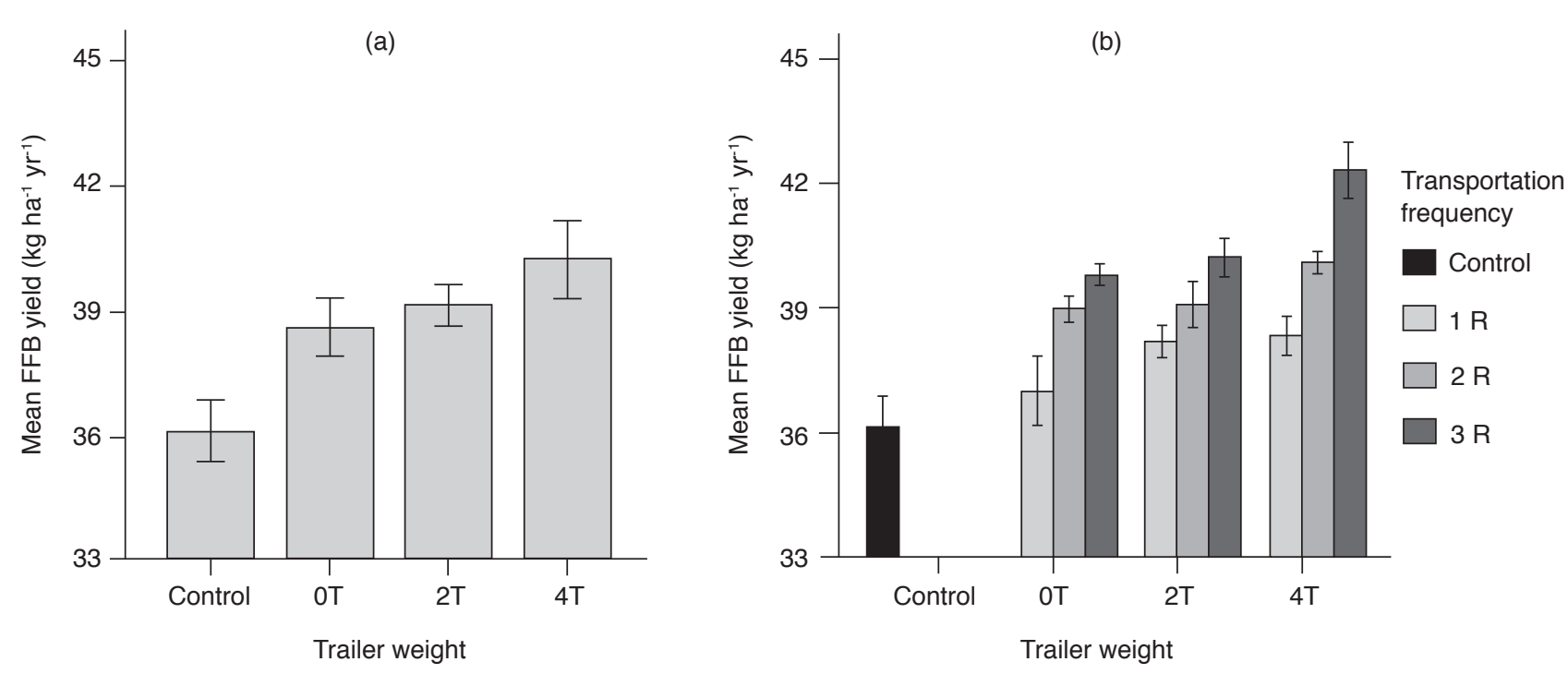

Figure 2. Fresh fruit bunch (FFB) yield affected by (a) trailer weights and (b) transportation frequencies.

For growing plants, pore size is more important than total pore space as larger void space could lead to poor root contact with the surrounding soil. Therefore, some degree of compaction is desirable to provide a suitable soil density for plant growth in low BD soils. Increase in soil BD and reduced TP could provide better root contact with surrounding soil and enhance nutrient uptake which would result in better oil palm yield.

FFB yields were found to have a positive relationship with increment in $\mathrm{BD}$, but a negative relationship with increment in TP (Figure 1). Higher soil BD in the compacted plots may have enhanced the soil's ability to retain water due to increase in the amount of meso- and micropores. Conducive soil condition exists when there are sufficient large pores to drain water promptly as well as adequate small pores to retain water which is the transport medium of nutrients available for plant growth. This condition also increases the nutrient mobility rates to roots by diffusion and mass flow in the soil (Russell, 1982). The previous study done by Zuraidah et al. (2015b) found that the oil palm roots had adapted to the changes in soil physical characteristics. Palms in control plots had produced a greater root biomass, while those in compacted plots showed a decreasing trend with increasing trailer weight. However, the reduction in total root biomass was compensated with higher tertiary and quaternary roots biomass to fit into smaller soil pores. This lead to a significant increase in root surface area for better water and nutrient uptake. These alterations had been beneficial to the palms, hence, contributing to higher FFB yield.

A similar trend as in FFB yield was observed for bunch number produced per palm per year. The bunch number was significantly increased $(\mathrm{p} \leq 0.05)$ by about $7 \%-9 \%$ in the compacted plots as compared to control (Figure 3a). However, there was no significant difference between bunch numbers produced in all compacted plots. The higher FFB yield in compacted plots (Figure 2a) was due to higher bunch number produced. Similarly, the bunch number per palm per year also increased with increasing transportation frequency (Figure $3 b$ ). The mean bunch number produced in control plots was 14 bunches per palm per year. However, the $4 \mathrm{~T}$ treatment at $3 \mathrm{R}$ transportation frequency per month produced the highest mean bunch number of 17 bunches per palm per year. Palms planted on compacted plots subjected to higher transportation frequency resulted in producing higher bunch numbers. The effects of transportation frequency were more significant than trailer weight in influencing palm bunch number (Figure $3 b$ ) and subsequently FFB yield (Figure 2). This could be attributed to improved nutrient uptake associated with higher available water in the compacted plots (Zuraidah et al., 2015a).

Figure $4 a$ shows that the mean bunch weight increased with increasing trailer weight. The palms in $4 \mathrm{~T}$ plots produced mean bunch weight of $18.01 \mathrm{~kg}^{\text {bunch }}{ }^{-1}$ which was significantly heavier $(\mathrm{p} \leq 0.05)$ by $2.6 \%$ compared to control which had a mean of $17.56 \mathrm{~kg}$ per bunch. Although higher, the mean bunch weight produced in $0 \mathrm{~T}$ and $2 \mathrm{~T}$ did not differ significantly with control. Subsequently, there was a non-significant increase in the bunch weight with increasing transportation frequency in all compacted plots Figure $4 b$.

\section{CONCLUSION}

The compaction treatments had significantly increased the soil BD while reducing TP. There was a positive relationship between the increased 
(a)

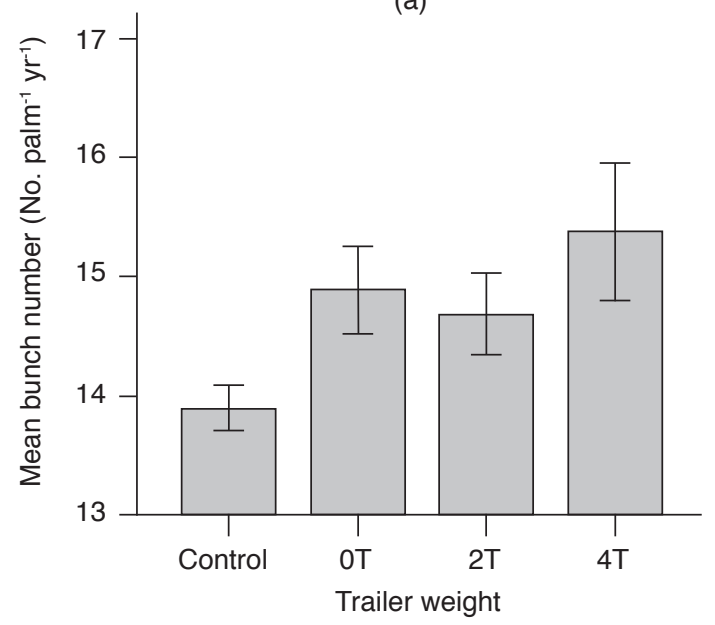

(b)

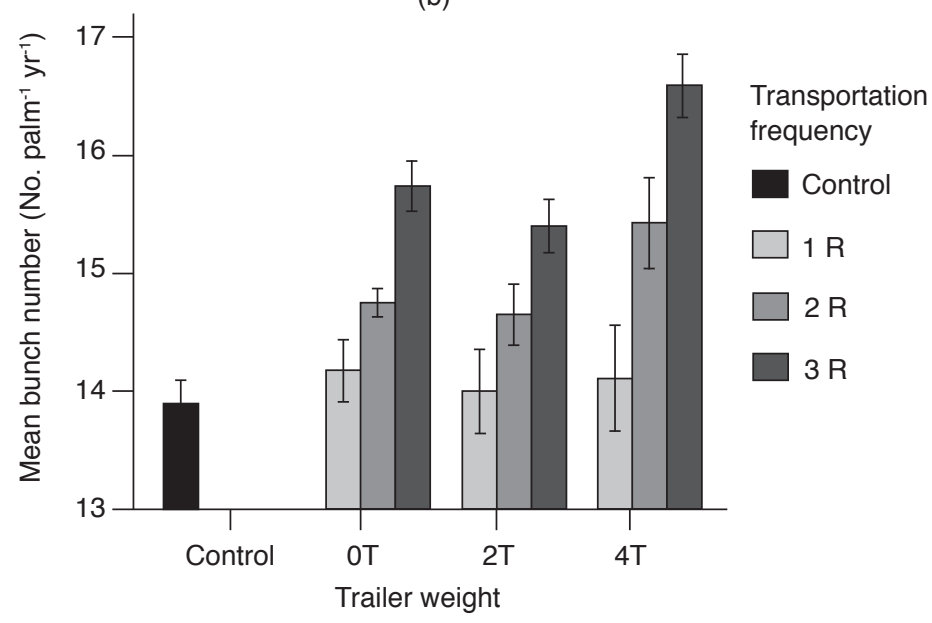

Figure 3. Bunch number affected by (a) trailer weights and (b) transportation frequencies.

(a)

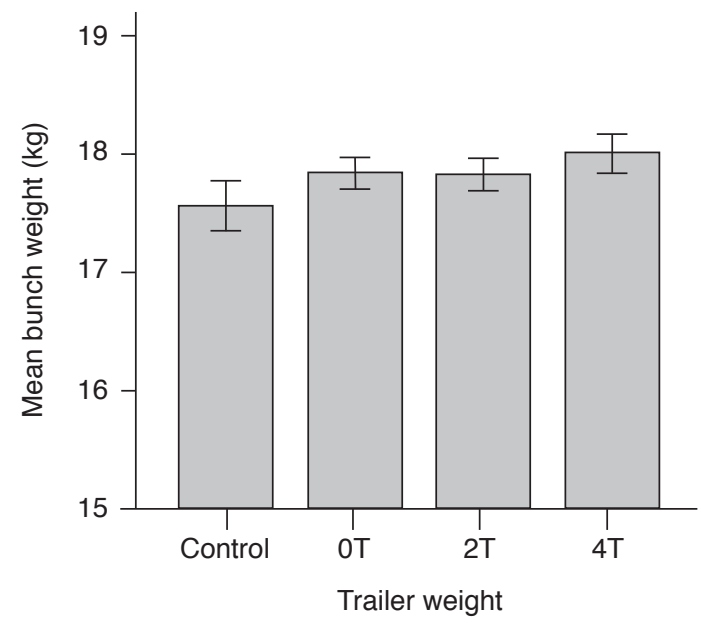

(b)

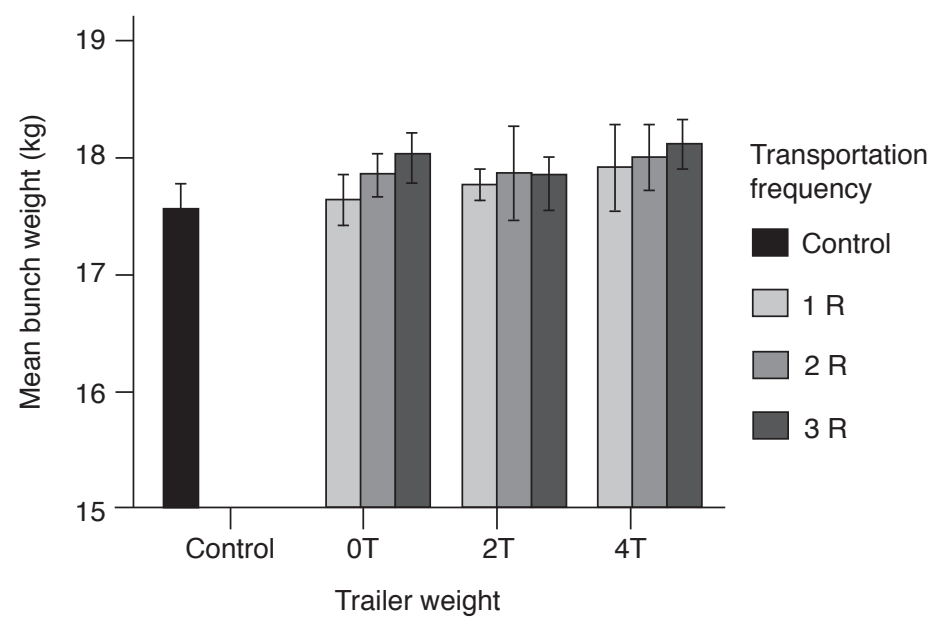

Figure 4. Bunch weight affected by (a) trailer weights and (b) transportation frequencies.

soil BD and oil palm FFB yield, which shows that the oil palm had benefited from the compaction treatments. With increasing trailer weights and transportation frequencies, the total FFB yield increased significantly since higher bunch number was produced. Although it is believed that soil compaction could cause yield reduction, this study showed otherwise. However, further study needs to be carried out in other soil series to determine any variations in response of oil palm to the compaction treatments.

\section{ACKNOWLEDGEMENT}

The author would like to thank the DirectorGeneral of MPOB for permission to publish this article. Special gratitude also goes to all members of the Agronomy and Geospatial Technology Unit, MPOB for their excellent help.

\section{REFERENCES}

Abu-Hamdeh, N H (2003). Compaction and subsoiling effects on corn growth and soil bulk density. Soil Science Society of America J., 67: 12131219.

Ares, A; Terry, A T; Miller, R E; Anderson, H W and Flaming, B L (2005). Ground-based forest harvesting effects on soil physical properties and Douglas-fir growth. Soil Science Society of America J., 69: 18221832.

Al-Ghazal, A A (2002). Effects of tractor wheel compaction on bulk density and infiltration rate of a loamy sand soil in Saudi Arabia. Emir. J. Agric. Sci., 14: 24-33.

Baiyeri, M R (2015). Effect of tractor wheel compaction on soil for crop yield (a case study of Lower Niger River Basin Farm). J. Research in Pure and Applied Sciences, 5(1): 8-14. 
Blake, G R and Hartge, K H (1986). Methods of Soil Analysis. Part 1. Physical and Mineralogical Methods. Second edition. ASA-SSSA. p. 364-367.

Cassel, D K; Razkowski, CW and Denton, HP (1995). Tillage effects on corn production and soil physical conditions. Soil Sci. Soc. Am. J., 59: 1436-1443.

Chan, K Y; Oates, A; Swan, A D; Hayes, R C; Dear, B $S$ and Peoples, M B (2005). Agronomic consequences of tractor wheel compaction on a clay soil. Soil and Tillage Research, 89: 13-21.

Dejong-Hughes, J; Moncrief, J F; Vorhees, W B and Swan, J B (2001). Soil Compaction: Causes, Effects and Control. Communication and Educational Technology Services, University of Minnesota Extension Service. http://extension.umn.edu/ distribution/cropsystems / DC3115.html

Duiker, S W (2004). Effects of soil compaction. Pennsylvania State University (Penn State's College of Agricultural Sciences Research). Produced by Information and Communication Technologies in the College of Agricultural Sciences. European J. Lipid Science and Technology, 109: 289-295.

Glab, T (2007). Effect of soil compaction on root system development and yields of tall Fescue. International Agrophysics, 21: 233-239.

Hamza, M A and Anderson, W K (2005). Soil compaction in cropping system. A review of the nature, causes and possible solutions. Soil and Tillage Research, 28(2): 121-145.

Hanna, M and Mahdi, M A (2002). Understanding $\mathcal{E}$ Managing Soil Compaction (Peterse, T S ed.). Published by Iowa State University. http:// www.ipm.iastate.edu/ipm / icm / 2002 / 7-8-2 / soilcompact.html

Kamaruzaman, J (1991). Effect of tracked and rubber-tyred logging machines on soil physical properties of the Berkelah Forest Reserve, Malaysia. Pertanika, 14: 265-276.

Lipiec, J; Medvedev, V V; Birka, M; Dumitru, E; Lyndina, T E; Rousseva, S and Fulajtár, E (2003). Effect of soil compaction on root growth and crop yield in Central and Eastern Europe. International Agrophysics, 17: 61-69. www.ipan.lublin.pl/intagrophysics

Mari, G R and Changying, J (2008). Influence of agricultural machinery on soil compaction patterns, root development and plant growth, overview. Am. Eurasian J. Agric. Environ. Sci., 3: 49-62.
Kushairi, A; Soh Kheang Loh; Azman, I; Elina Hishamuddin; Meilina Ong-Abdullah; Zainal Bidin Mohd Noor Izuddin; Razmah, G; Shamala Sundram and Ghulam Kadir Ahmad Parveez (2018). Oil palm economic performance in Malaysia and R\&D progress in 2017. J. Oil Palm Res. Vol. 30(2): 163-195.

Pagliai, M; Marsili, A; Servadio, P; Vignozzi, N and Pellegrini, S (2003). Changes in some physical properties of a clay soil in Central Italy following the passage of rubber tracked and wheeled tractors of medium power. Soil Tillage Research, 73: 119-129.

Ponder, F (2004). Soil compaction affects growth of young shortleaf pine following litter removal and weed control in the Missouri Ozarks. Proc. of the $14^{\text {th }}$ Central Hardwoods Forest Conference GTR-NE-316. p. 255-263.

Raper, L R and Kirby, J M (2006). Soil Compaction: How to Do It, Undo It or Avoid Doing It. Agricultural Equipment Technology Conference, Louisville, Kentucky, USA. American Society of Agricultural and Biological Engineers. p. 1-14.

Russell, R S (1982). The soil environment. Responses to soil conditions. Plant Root System: Their Function and Interaction with the Soil. McGrawHill Book Company (UK) Limited, Berkshire, England. p. 143157.

Townend, J; Reeve, M J and Carter, A (2001). Water release characteristics. Soil and Environmental Analysis. Physical Methods (Smith, K A and Mullins, C E eds.). Second edition. Revised and Expanded. Publisher: Marcel, Dekker Inc. p. 111.

Usaborisut, P and Niyamapa, T (2010). Effects of machine-induced soil compaction on growth and yield of sugarcane. American J. Agricultural and Biological Sciences, 5(3): 269-273.

Zhang, X Y; Cruise, R M; Sui, Y Y and Jhao, Z (2006). Soil compaction induced by small tractor traffic in Northeast China. Soil Science Society of America J., 70: 613-619.

Zuraidah, Y; Zulkifli, H; Haniff, M H; Nur Zuhaili, H A Z A; Nordiana, A A; Shuib, A R; Afifah, A R and Nur Maisarah, J (2015a). Alterations of soil physical properties due to mechanisation activities under oil palm on Bernam Series Soil. International J. Agriculture Innovations and Research, 3(5): 14351446.

Zuraidah, Y; Haniff, M H and Zulkifli, H (2015b). Oil palm roots adaptation under soil compacted by mechanisation. International J. Agricultural Science and Research, 5(4): 331-342. 